
cited.

\title{
PENEGAKAN HUKUM KEHUTANAN DALAM UNDANG-UNDANG NOMOR 18 TAHUN 2013 TENTANG PENCEGAHAN DAN PEMBERANTASAN PERUSAKAN HUTAN DITINJAU DARI PERSPEKTIF KEADILAN MASYARAKAT HUKUM ADAT
}

\author{
Rugun Romaida Hutabarat \\ (Dosen Fakultas Hukum Universitas Tarumanagara Jakarta) \\ (E-mail : rugun@ fh.untar.ac.id) \\ Luisa Srihandayani \\ Kexia Goutama \\ Yoefanca Halim \\ (Mahasiswa Program S1 Fakultas Hukum Universitas Tarumanagara Jakarta)
}

Received: 28 Mei 2018; Accepted: 29 Mei 2019; Published: 30 Juni 2019

\begin{abstract}
:
Forest destructions has been escalating worldwide, including in Indonesia. Therefore, the Government issued Law Number 18/2013 on the Prevention and Eradiction of Deforestation (P3H) which was expected to guarantee legal certainty with emphasis on eradication of organized forest destruction. The problem to be discussed in this paper is about law enforcement and application of Law Number 18 / 2013 which frequently used to criminalize the indigenous people in Indonesia. The indigenous people have been criminalized on the ground of unlawful forest products utilization, while they merely foraging to fulfill their basic necessities. The criminalization of indigenous people is a conclusive evidence, which proof that Indonesian Goverment has been neglecting the indigenous people's right. This paper use normative approach. The conclusion of this paper analyze that the problem of the criminalization happens in implementation level, which caused by the ignorance of law enforcement apparatus and vested interest.
\end{abstract}

Keywords: Law Enforcement, Application of Law No. 18 year 2013, Criminalization, Indigenous People.

\section{Pendahuluan}

\section{A. Latar Belakang}

Negara dan konstitusi dapat diumpamakan ibarat dua sisi mata uang logam, yang satu sama lainnya saling berkaitan untuk dapat menjadi satu kesatuan yang sempurna. Oleh karena itu, negara dan konstitusi merupakan dua hal yang tidak dapat dipisahkan antara satu dengan yang lainnya. UUD NRI Tahun 1945 (UUD NRI 1945) merupakan konstitusi negara Indonesia yang mencakup latar belakang, hasrat bernegara, landasan filosofi kenegaraan, dan tujuan negara yang diinginkan oleh bangsa yang mendirikan dan mempertahankan negara Indonesia. ${ }^{1}$

1 Dahlan Thaib, Teori dan Hukum Konstitusi, (Jakarta: Raja Grafindo Persada, 2001), hlm. 16. 


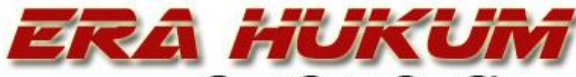 Gurnal Glmiah Glmu Glukum \\ Vol. 16, No. 2, Oktober 2018}

Salah satu tujuan nasional yang tercantum dalam Alinea IV Pembukaan UUD NRI 1945 yaitu "Memajukan kesejahteraan sosial." Hal ini menjadi landasan bahwa secara substansi UUD NRI 1945 tidak hanya terkait dengan pengaturan lembaga-lembaga negara dan struktur pemerintahan semata, namun lebih daripada itu, konstitusi juga sejatinya memiliki dimensi pengaturan ekonomi dan kesejahteraan sosial yang secara khusus tertuang di dalam Pasal 33 UUD NRI $1945 .^{2}$ Pasal ini merupakan bukti yang menunjukkan bahwa Indonesia adalah negara kesejahteraan. ${ }^{3}$ Tak hanya itu, pasal ini juga mencerminkan cita-cita, suatu keyakinan yang dipegang teguh serta diperjuangkan secara konsisten oleh para pimpinan pemerintahan. ${ }^{4}$ Pasal 33 ayat (2) dan (3) amandemen 4 (empat) UUD NRI 1945, menyebutkan:

“(2) Cabang-cabang produksi yang penting bagi Negara dan yang menguasai hajat hidup orang banyak dikuasai oleh Negara

(3) Bumi, air dan kekayaan alam yang terkandung didalamnya dikuasai oleh Negara dan

\footnotetext{
${ }^{2}$ Dimensi pengaturan ekonomi dan kesejahteraan sosial yang tertuang di dalam Pasal 33 dan 34 UUD 1945. Pasal ini merupakan konsekuensi dari tujuan dari berdirinya negara Indonesia, hal ini ditunjukkan di dalam Pembukaan UUD 1945 pada alinea ke-4, yang rumusannya sebagai berikut: "Kemudian daripada itu untuk membentuk suatu pemerintah

${ }^{3}$ Jimly Asshiddiqie, Green Constitution: Nuansa Hijau Undang-Undang Dasar Negara Republik
}

Rugun Romaida Hutabarat, Luisa Srihandayani Kexia Goutama dan Yoefanca Halim Penegakan Hukum Kehutanan...

dipergunakan untuk sebesarbesarnya kemakmuran rakyat"

Selanjutnya, Pasal 33 ayat (3) tersebut dijabarkan dalam UndangUndang No. 5 Tahun 1960 tentang Peraturan Dasar Pokok-Pokok Agraria (UUPA). Pasal 2 ayat (1) UUPA menyatakan: "Atas dasar ketentuan dalam Pasal 33 ayat (3) Undang-Undang Dasar dan hal-hal sebagai yang dimaksud dalam pasal 1, bumi air dan ruang angkasa, termasuk kekayaan alam yang terkandung di dalamnya itu pada tingkatan tertinggi dikuasai oleh Negara, sebagai organisasi kekuasaan seluruh rakyat." Secara konkret, contoh salah satu unsur kekayaan alam adalah hutan.

Hutan merupakan sumber daya alam yang memiliki nilai strategis dalam pembangunan bangsa dan negara yang dikuasai oleh negara dan dipergunakan untuk kesejahteraan rakyat secara keseluruhan. ${ }^{5}$ Namun, dalam diskursus Hak Asasi Manusia (HAM), khususnya hak masyarakat adat, terdapat banyak sekali permasalahan mengenai

Indonesia Tahun 1945, (Jakarta: Rajawali Pers, 2009), hlm. 79.

4 Bagir Manan, Pertumbuhan dan Perkembangan Konstitusi Suatu Negara, Bandung: Mandar Maju, 1995, hlm. 45.

5 Salim, Hukum, Kehutanan \& Hukum Perkebunan di Indonesia, (Jakarta:Sinar Grafika, 2010), Cet. 1 , hlm 17 


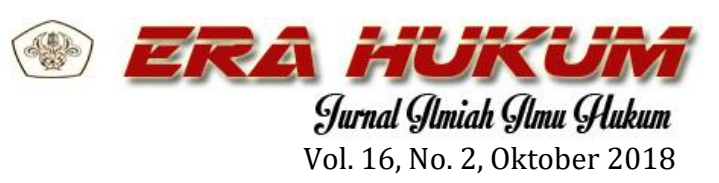

penegakan hukum bagian hak ekonomi, sosial dan budaya. Mekanisme penegakan hak tersebut sangat sulit karena belum terdapat instrumen hukum yang jelas dan matang untuk menjamin dan menegakkan hak masyarakat adat.

Sumber daya hutan seharusnya dapat dimanfaatkan secara optimal bagi kemakmuran rakyat dalam jangka panjang, baik untuk saat ini maupun untuk generasi yang akan datang dengan tetap mendasarkan kepada pemanfaatan hutan yang lestari, dan juga harus menghormati hak masyarakat adat setempat. Mengacu pada pasal 67 ayat (1) UU Nomor 41 Tahun 1999 tentang Kehutanan (UU Kehutanan) dinyatakan bahwa masyarakat hukum adat sepanjang menurut kenyataannya masih ada dan diakui keberadaannya, berhak: ${ }^{6}$

a) melakukan pemungutan hasil hutan untuk pemenuhan kebutuhan sehari-hari masyarakat adat yang bersangkutan;

b) melakukan kegiatan pengelolaan hutan berdasarkan hukum adat yang berlaku dan tidak bertentangan dengan undangundang;

c) mendapatkan pemberdayaan dalam rangka meningkatkan kesejahteraannya

\footnotetext{
${ }^{6}$ Undang-undang nomor 41 Tahun 1999 Tentang Kehutanan

7 Artikel, Arimbi Ramadhiani, "Area Konflik Agraria Terluas di Sektor Perkebunan dan
}

Rugun Romaida Hutabarat, Luisa Srihandayani Kexia Goutama dan Yoefanca Halim Penegakan Hukum Kehutanan...

Faktanya, pasal-pasal tersebut tidak mampu memberikan keadilan dan perlindungan bagi masyarakat hukum adat. Pelanggaran masif di bidang hak adat, seperti pembalakan hutan ulayat masih belum terjangkau oleh negara. Bahkan, bukannya berupaya untuk memulihkan hak masyarakat hukum adat dari berbagai pelanggarannya, terkadang negara justru mempelopori pengkriminalisasian masyarakat hukum adat tersebut. Hal ini mengakibatkan konflik agraria di sektor kehutanan yang hingga kini belum mampu diselesaikan oleh pemerintah. Bila dilihat dari jumlah konflik agraria, posisi pertama ditempati oleh sektor perkebunan sebesar 127 konflik dan disusul sektor infrastruktur sebanyak 70 konflik. Dari total area konflik agraria seluas 400.430,00 hektar, area konflik paling luas pada 2015 berada di sektor perkebunan dan sektor kehutanan. ${ }^{7}$ Hal ini dapat kita lihat pada UU Nomor 18 tahun 2013 tentang Pencegahan dan Pemberantasan Perusakan Hutan (UU P3H) yang sebenarnya ditujukan untuk melindungi hutan dari kerusakan dan kejahatan yang terorgasnisasi maupun lintas negara yang dilakukan dengan modus operandi

Kehutanan", https://properti.kompas.com/read/2 016/01/06/061504721/Area.Konflik.Agraria.Ter luas.di.Sektor.Perkebunan.dan.Kehutanan, diakses tanggal 14 April 2018. 


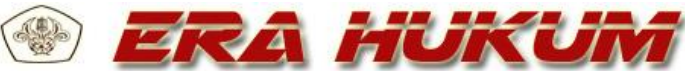 Gurnal Glmiah Glmu Glukum}

Vol. 16, No. 2, Oktober 2018

Rugun Romaida Hutabarat, Luisa Srihandayani Kexia Goutama dan Yoefanca Halim Penegakan Hukum Kehutanan...

yang canggih. ${ }^{8}$ Tetapi, justru digunakan oleh aparat pemerintah untuk mengkriminalisasi masyarakat hukum adat yang melakukan perladangan tradisional atau pemungutan hasil hutan untuk pemenuhan kebutuhan hidup sehari-hari. Peningkatan kriminalisasi ini dapat dilihat dari banyaknya jumlah masyarakat hukum adat, masyarakat lokal, dan masyarakat desa yang dipenjarakan karena bersinggungan dengan kawasan hutan. Berdasarkan hal tersebut, tulisan ini akan membahas mengenai bagaimana eksistensi masyarakat hukum adat dan hak ulayat kehutanan di Indonesia dan bagaimana penegakan hukum kehutanan dalam UU P3H ditinjau dari perspektif keadilan hukum hutan adat.

\section{B. Metode Penelitian}

Metode yang digunakan dalam tulisan ini adalah yuridis normatif yaitu penelitian kepustakaan (Librarian Research), berupa penelitian terhadap data. Sedangkan data primer dalam

\footnotetext{
${ }^{8}$ Konsiderans huruf e Undang-Undang Nomor 18 tahun 2013 tentang Pencegahan dan Pemberantasan Perusakan Hutan. "bahwa perusakan hutan sudah menjadi kejahatan yang berdampak luar biasa, terorganisasi, dan lintas negara yang dilakukan dengan modus operandi yang canggih, telah mengancam kelangsungan kehidupan masyarakat sehingga dalam rangka pencegahan dan pemberantasan perusakan hutan
}

penelitian ini hanya sebagai data penunjang. ${ }^{9} \quad$ Penelitian ini juga menggunakan beberapa pendekatan yaitu pendekatan perundang-undangan (statute approach) dilakukan dengan menelaah semua undang-undang dan regulasi yang berkaitan dengan isu hukum yang ditangani ${ }^{10}$. Adapun, isu hukum yang ditangani dalam tulisan ini adalah problematika penegakan dan pengimplementasian $\mathrm{UU} \quad \mathrm{P} 3 \mathrm{H}$ bagi masyarakat hukum adat. Pendekatan yang digunakan adalah pendekatan yuridis normatif yaitu dengan mengkaji atau menganalisis data sekunder yang terdiri dari berbagai literatur maupun jurnal yang membahas mengenai masyarakat adat dan hak ulayatnya. Hasil penelitian ini bersifat deskriptif analitis dan preskriptif. Deskriptif analitis yaitu suatu penelitian yang dilakukan secara deskriptif, terbatas pada usaha mengungkapkan suatu masalah dan keadaan sebagaimana adanya, sehingga hanya bersifat mengungkap atau memaparkan suatu peristiwa maupun fakta yang ada secara

\footnotetext{
yang efektif dan pemberian efek jera diperlukan landasan hukum yang kuat dan yang mampu menjamin efektivitas penegakan hukum."

9 Rony Hanitiyo Soemitro, Metode Penelitian Hukum dan Juri Metri, (Jakarta: Ghalia Indonesia, 1994), hlm. 5.

10 Peter Mahmud Marzuki, Penelitian Hukum, (Jakarta: Kencana, 2010), hlm. 93.
} 


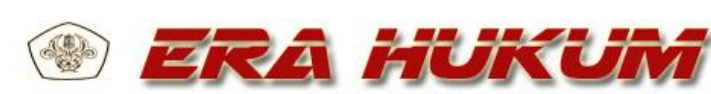

Gurnal Glmiah Glmu Glukum

Vol. 16, No. 2, Oktober 2018

rinci, sistematis, dan menyeluruh sedangkan preskriptif merupakan pemecahan atas isu hukum yang diajukan dan secara etimologi berarti apa yang seharusnya. ${ }^{11}$

\section{Hasil dan Pembahasan}

\section{Eksistensi Masyarakat Hukum Adat dan Hak Ulayat Kehutanan di Indonesia}

Menurut Kusumadi Pujosewojo adalah masyarakat yang timbul secara spontan di wilayah tertentu, berdirinya tidak ditetapkan atau diperintahkan oleh penguasa yang lebih tinggi atau penguasa lainnya, dengan rasa solidaritas sangat besar diantara anggota, memandang bukan anggota masyarakat sebagai orang luar dan menggunakan wilayahnya sebagai sumber kekayaan yang hanya dapat dimanfaatkan sepenuhnya oleh anggotanya. ${ }^{12}$

Eksistensi masyarakat hukum adat masih sangat mengakar di Indonesia, dilihat dari keberadaan wilayah masyarakat hukum adat di Indonesia yang menurut hasil penelitian Van Vollenhoven terdapat 19 wilayah hukum adat yaitu: (1) Aceh, (2) Gayo, Alas,

${ }^{11}$ Titon Slamet Kurnia dkk, Pendidikan Hukum, Ilmu Hukum dan Penelitian Hukum Di Indonesia:Sebuah Reorientasi, (Yogyakarta: Pustaka Pelajar, 2013), hlm. 129.

12 Maria S.W Sumardjono, Kebijakan Pertanahan, antara Regulasi dan Implementasi, Penerbit Buku Kompas, Jakarta 2001., hal.56
Rugun Romaida Hutabarat, Luisa Srihandayani Kexia Goutama dan Yoefanca Halim Penegakan Hukum Kehutanan...

Batak dan Nias (3) Minangkabau, Mentawai, (4) Sumatera Selatan, Enggano, (5) Melayu, (6) Bangka, Belitung, (7) Kalimantan, (8) Minahasa, (9) Gorontalo, (10) Toraja, (11) Sulawesi Selatan, (12) Kepulauan Ternate, (13) Maluku, (14) Irian Barat,

Kepulauan Timor, (16) Bali, Lombok, (17) Jawa Tengah, Jawa Timur, Madura, (18) Solo, Yogyakarta, (19) Jawa Barat, Jakarta. $^{13}$

Pada tahun 1999, Kongres Masyarakat Adat Nusantara I (KMAN I) menetapkan definisi kerja bagi Komunitas Masyarakat Adat sebagai "Komunitas-Komunitas yang hidup berdasarkan asal-usul leluhur secara turun-temurun di atas suatu wilayah adat, yang memiliki kedaulatan atas tanah dan kekayaan alam, kehidupan sosial budaya yang diatur oleh hukum adat, dan lembaga adat yang mengelola keberlangsungan kehidupan masyarakatnya". ${ }^{14}$ Definisi tersebut menunjukkan adanya keterkaitan yang erat antara masyarakat hukum adat dengan kedaulatan atas tanah dan

13 Husen Alting, Dinamika Hukum dalam Pengakuan dan Perlindungan Hak Masyarakat Hukum Adat atas Tanah, Yogyakarta, 2010.,hal. 31

${ }^{14}$ http://www.aman.or.id/wpcontent/uploads/2017/02/PROFILAMAN_Update Bahasa_Oct2016.pdf, diakses pada tanggal 23 Maret 2018. 


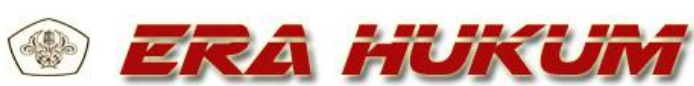
Gurnal Glmiah Glmu Glukum

Vol. 16, No. 2, Oktober 2018

Rugun Romaida Hutabarat, Luisa Srihandayani Kexia Goutama dan Yoefanca Halim Penegakan Hukum Kehutanan...

kekayaan alam sebagai milik masyarakat hukum adat itu. Hak yang dimiliki masyarakat hukum adat untuk menguasai tanah serta memanfaatkan kekayaannya atas tanah itu, yang berada dalam lingkungan wilayah tertentu inilah yang disebut dengan hak ulayat. Menurut Boedi Harsono, hak ulayat merupakan wewenang dan kewajiban suatu masyarakat hukum adat, yang berhubungan dengan tanah yang terletak dalam lingkungan wilayahnya, yang merupakan pendukung utama penghidupan dan kehidupan masyarakat yang bersangkutan sepanjang masa. ${ }^{15}$

Eksistensi masyarakat hukum adat dan hak ulayat itu sendiri masih diakui dalam Pasal 18 B ayat (2) UUD NRI 1945 yang menyatakan bahwa "Negara mengakui dan menghormati kesatuankesatuan masyarakat hukum adat beserta hak-hak tradisionalnya sepanjang masih hidup dan sesuai dengan perkembangan masyarakat dan prinsip Negara Kesatuan Republik Indonesia”. Adanya pengakuan hak ulayat inipun tercantum dalam Pasal 3 UUPA yang menyebutkan bahwa "Pelaksanaan hak ulayat dan hakhak yang serupa itu dari masyarakatmasyarakat hukum adat, sepanjang

${ }^{15}$ Suriyaman Mustari Pide, Hukum Adat Dahulu, Kini, dan Akan Datang, (Jakarta: Prenadamedia Group, 2014), hlm. 119.

menurut kenyataannya masih ada, harus sedemikian rupa sehingga sesuai dengan kepentingan nasional dan negara, yang berdasarkan atas persatuan bangsa serta tidak boleh bertentangan dengan undang-undang dan peraturan-peraturan lain yang lebih tinggi”. Mahkamah konstitusi melalui Putusan Nomor 31/PUU-V/2007 menegaskan setidaknya ada lima kriteria agar masyarakat hukum adat dikatakan "masih hidup", baik yang bersifat teritorial, geneologis, maupun yang bersifat fungsional yaitu: (1) adanya masyarakat yang warganya memiliki perasaan kelompok (in- group feeling); (2) adanya pranata pemerintahan adat; (3) adanya harta kekayaan dan/atau benda-benda adat; (4) adanya perangkat norma hukum adat; (5) Khusus pada kesatuan masyarakat hukum adat yang bersifat teritorial juga terdapat unsur adanya wilayah tertentu.

Adapun contoh konkret pengakuan mengenai eksistensi masyarakat hukum adat dan hak ulayatnya dapat kita lihat pada UU Nomor 21 Tahun 2001 tentang Otonomi Khusus Bagi Provinsi Papua, Hak Ulayat adalah hak persekutuan yang dipunyai oleh masyarakat hukum adat tertentu atas suatu wilayah tertentu yang 


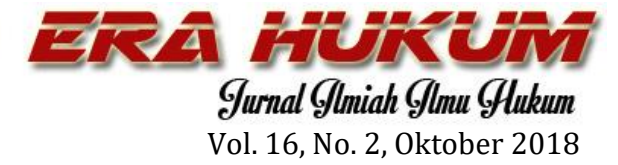

merupakan lingkungan hidup para warganya, yang meliputi hak untuk memanfaatkan tanah, hutan, dan air serta isinya sesuai dengan peraturan perundang-undangan. ${ }^{16}$

Pemanfaatan hutan oleh masyarakat hukum adat dapat dikaitkan dengan kedudukan hak ulayat dalam hak menguasai negara, dimana pada pasal 2 ayat (4) UUPA menyebutkan bahwa "Hak menguasai dari Negara tersebut di atas pelaksanaannya dapat dikuasakan kepada daerah-daerah swatantra dan masyarakat-masyarakat hukum adat, sekedar diperlukan dan tidak bertentangan dengan kepentingan nasional, menurut ketentuan-ketentuan Peraturan Pemerintah". ${ }^{17}$ Adanya pengaturan tersebut memperlihatkan bahwa kedudukan hak ulayat bukan lagi merupakan wewenang absolut dari masyarakat karena kewenangannya itu ditentukan oleh mandat negara. ${ }^{18}$ Namun demikian Pasal 2 ayat (4) UUPA tersebut tidak ditindaklanjuti dengan peraturan

${ }^{16}$ Pasal 1 huruf s UU Nomor 21 Tahun 2001 tentang Otonomi Khusus Bagi Provinsi Papua.

${ }^{17}$ Memperjelas hal tersebut, Penjelasan II angka (3) UUPA menyatakan bahwa "Kepentingan sesuatu masyarakat hukum harus tunduk pada kepentingan nasional dan Negara yang lebih luas dan hak ulayatnya pun pelaksanaannya harus sesuai dengan kepentingan yang lebih luas itu. Tidaklah dapat dibenarkan, jika di dalam alam bernegara dewasa ini sesuatu masyarakat hukum masih mempertahankan isi dan pelaksanaan hak ulayatnya secara mutlak, seakan-akan ia terlepas daripada hubungannya dengan masyarakat-
Rugun Romaida Hutabarat, Luisa Srihandayani Kexia Goutama dan Yoefanca Halim Penegakan Hukum Kehutanan...

yang lebih rendah untuk operasionalisasinya sehingga masyarakat hukum adat seringkali hanya diberikan hak untuk memanfaatkan sumber daya hutan. ${ }^{19}$ Hal ini dapat dilihat dalam Undang-Undang No. 41 Tahun 1999 tentang Kehutanan, Undang-Undang Nomor 27 Tahun 2007 tentang Pengelolaan Wilayah Pesisir dan Pulau-Pulau Kecil, Undang-Undang Nomor 18 Tahun 2013 tentang Pencegahan dan Pemberantasan Perusakan Hutan, dan berbagai peraturan perundang-undangan lain.

Kedudukan hak ulayat dalam masyarakat hukum adat ini semakin lemah dengan adanya Peraturan Pemerintah Nomor 24 Tahun 1997 tentang Pendaftaran Tanah karena Keberadaan Hak Ulayat di Indonesia hanya sebatas diakui oleh peraturanperaturan yang ada akan tetapi tidak disertai dengan pendaftaran atas hak tersebut $^{20}$ sehingga dianggap tidak memiliki bukti yang kuat dan terus-

masyarakat hukum dan daerah-daerah lainnya di dalam lingkungan Negara sebagai kesatuan”.

${ }^{18}$ Ibid., hlm. 125.

19 Bambang Daru Nugroho, "Pengelolaan Hak Ulayat Kehutanan yang Berkeadilan dalam Kaitan Pemberian Izin HPH Dihubungkan dengan Hak Menguasai Negara atas Sumber Daya Alam", Jurnal Hukum Litigasi, Volume 11 Nomor 1, April 2010, hlm. 416.

${ }^{20}$ Pasal 9 ayat (1) Peraturan Pemerintah Nomor 24 Tahun 1997 tentang Pendaftaran Tanah menyatakan bahwa obyek pendaftaran tanah meliputi: a. Bidang-bidang tanah yang dipunyai 


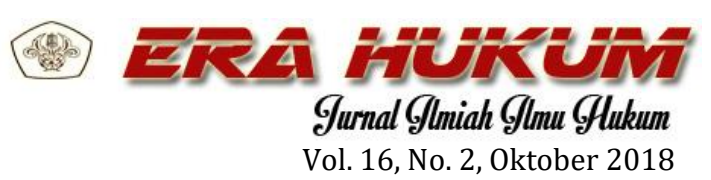

menerus kalah dengan pemerintah atau pemegang izin hak pengelolaan hutan yang memiliki kelengkaan bukti pemilikan dan penguasaan. $^{21}$ Bahkan, sekarang ini banyak masyarakat hukum adat dikriminalisasi karena wilayahnya yang digunakan untuk aktivitas perladangan tradisional atau dimanfaatkan untuk pemenuhan kebutuhan sehari-hari diklaim sebagai hutan negara yang masih belum jelas proses hukumnya ${ }^{22}$ ataupun diklaim sebagai hutan produksi yang harus dilindungi. Kenyataan demikian menunjukkan bahwa eksistensi masyarakat hukum adat dan hak ulayatnya masih ada dan diakui secara yuridis namun kurang mendapat perhatian dan perlindungan dari pemerintah Indonesia.

\section{Penegakan Hukum Kehutanan dalam UU P3H ditinjau dari Perspektif Keadilan Hukum Hutan Adat}

Sebagai konsekuensi Pasal 1 ayat (3) UUD NRI 1945 yang menyatakan bahwa, "Negara Indonesia adalah Negara Hukum", maka sudah

dengan hak milik, hak guna usaha, hak guna bangunan dan hak pakai. b. Tanah hak pengelolaan c. Tanah wakaf d. Hak milik atas satuan rumah susun e. Hak tanggungan $\mathrm{f}$. Tanah Negara.

${ }^{21}$ Ibid., hlm. 421.
Rugun Romaida Hutabarat, Luisa Srihandayani Kexia Goutama dan Yoefanca Halim Penegakan Hukum Kehutanan...

selayaknya negara memberikan jaminan pemenuhan dan perlindungan atas hakhak warga negara. Hal ini termasuk pula jaminan pemenuhan dan perlindungan hak bagi masyarakat hukum adat yang merupakan bagian dari warga negara Indonesia. Bahkan apabila dilihat secara historis, masyarakat hukum adat inilah yang sejak dahulu telah tinggal di wilayah Indonesia dan hidup dari berbagai kekayaan alam dalam batasanbatasan wilayahnya sendiri yang pada penjelasan sebelumnya disebut dengan hak ulayat.

Secara yuridis, pemerintah telah mengakui keberadaan masyarakat hukum adat beserta dengan hak-hak ulayatnya sebagaimana tercantum dalam Pasal 18 B Ayat (2) UUD NRI 1945, UUPA, Undang-Undang Nomor 39 Tahun 1999 tentang Hak Asasi Manusia (UU HAM), ataupun dalam peraturan perundang-undangan lain. Dari berbagai peraturan tersebut selalu dapat disimpulkan bahwa hak ulayat masyarakat hukum adat pun harus tunfuk dalam batasan-batasan hukum nasional dan memperhatikan kepentingan nasional. Namun, tentu pemerintah tidak

\footnotetext{
${ }^{22}$ http://www.aman.or.id/wpcontent/uploads/2015/05/Siaran-PersPernyataan-AMAN-dalam-Memperingati-2tahun-Putusan-MK-35.pdf, diakses pada tanggal 23 Maret 2018
} 


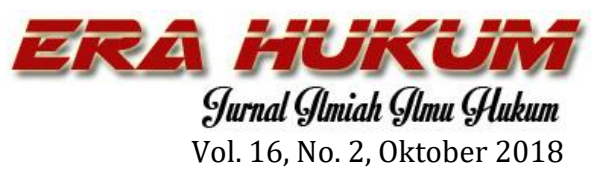

boleh sewenang-wenang ataupun seenaknya dalam mengatur mengenai hak ulayat masyarakat hukum adat tersebut. Mengingat hak ulayat itu merupakan salah satu hak paling fundamental bagi kesatuan masyarakat hukum adat yang tidak terpisahkan dalam kehidupan mereka.

Pada kenyataannya, berbagai landasan yuridis yang menyatakan bahwa negara menghormati, menghargai, dan melindungi hak masyarakat hukum adat tersebut belum dapat diwujudnyatakan secara optimal. Hal ini dapat dilihat dari salah satu permasalahan yang masih terus terjadi hingga sekarang yakni mengenai pengkriminalisasian masyarakat hukum adat yang berhubungan dengan kawasan hutan. Berdasarkan catatan Konsorsium Pembaruan Agraria (KPA), konflik agraria sepanjang tahun 2004-2015 di sektor kehutanan berjumlah 164 konflik, yang secara tidak langsung juga telah menyebabkan 1.673 petani dan warga desa ditangkap dan dipidanakan secara

\footnotetext{
${ }^{23}$ http://www.kpa.or.id/news/blog/bebaskankakek-sudjana-hentikan-kriminalisasi-petanihapus-uu-p3h-jalankan-reforma-agraria/, diakses pada tanggal 23 Maret 2018.

${ }^{24}$ Ibid.

${ }^{25}$ Undang-undang No. 41 Tahun 1999 Tentang Kehutanan

26 Menurut Mahdi (dalam Abdurahman dan Wentzel, 1997:56) hutan adat adalah kawasan hutan yang berada di dalam wilayah adat yang
}

Rugun Romaida Hutabarat, Luisa Srihandayani Kexia Goutama dan Yoefanca Halim Penegakan Hukum Kehutanan...

paksa. ${ }^{23}$ Koalisi Anti-Mafia Hutan mencatat terdapat 53 warga yang telah terjerat UU $\mathrm{P} 3 \mathrm{H}, 43$ orang diantaranya divonis bersalah dengan hukuman 18 bulan penjara. Kondisi di atas menjadi gambaran betapa rentannya naib petani akibat keberadaan UU P3H. ${ }^{24} \mathrm{Hal}$ ini menggambarkan bahwa masyarakat hukum adat seringkali belum diperhatikan dan dilindungi oleh pemerintah Indonesia.

Perlu diketahui, pada Pasal 5 Ayat (1) Undang-undang No. 41 Tahun 1999 tentang Kehutanan (UU Kehutanan), disebutkan jenis-jenis hutan berdasarkan statusnya adalah: ${ }^{25}$

a. Hutan Negara adalah hutan yang berada dalam tanah yang tidak dibedani hak atas tanah.

b. Hutan hak adalah hutan yang berada pada tanah yang dibebani hak atas tanah.

Selanjutnya, Pasal 5 Ayat (2) UU Kehutanan menyebutkan : "Hutan Negara dapat berupa hutan adat ${ }^{26}$, yaitu hutan Negara yang diserahkan pengelolaanya kepada masyarakat hukum adat."

merupakan bagian yang tidak dapat terpisahkan dari siklus kehidupan komunitas adat penghuninya, merupakan hak ulayat masyarakat adat yang meliputi air, tumbuh-tumbuhan (pepohonan), binatang, bebatuan yang memiliki nilai ekonomis (di dalam tanah), bahan galian, dan juga sepanjang pesisir pantai, juga di atas permukaan air, di dalam air, maupun bagian tanah yang berada dialamnya. 


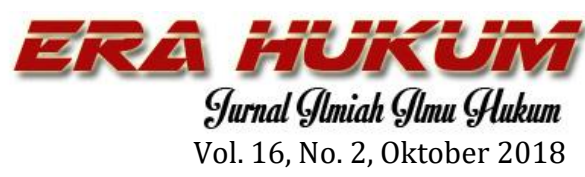

Sebelum adanya putusan MK No. 35/PUU-X/2012, walaupun istilahnya disebut sebagai "hutan adat", masyarakat hukum adat sesungguhnya tidak memiliki kekuasaan secara penuh atas jenis hutan ini. Melalui putusan MK No. 35/PUU-X/2012, prinsip-prinsip di atas telah dirubah secara cukup radikal. Sehingga, prinsip pengaturan dalam UU No. 41 Tahun 1999 menyangkut eksistensi hutan adat sekarang menjadi terpisah dari hutan negara. Hal ini merujuk pada pendapat MK yang menyatakan bahwa sesuai dengan pengaturan dalam pasal 18B Ayat (2) UUD 1945, kesatuan masyarakat hukum adat adalah suatu subyek hukum yang memiliki kapasitas untuk menyandang hak (dan kewajiban), dan oleh karenanya masyarakat hukum adat sudah seharusnya memiliki hak atas hutan. ${ }^{27}$

Mengingat hutan adat merupakan bagian dari hak ulayat masyarakat hukum adat, maka dalam pemanfaatannya hutan adat diatur oleh kepala suku. Sebagaimana ditegaskan oleh G. Kertasapoetra dan kawan-kawan dalam bukunya Hukum Tanah, Jaminan UUPA Bagi Keberhasilan Pendayagunaan Tanah, hak ulayat

${ }^{27}$ Safrin Salam Vol.7 No.2 Agustus 2016, hlm. 209-224.

28 G. Kertasapoetra, R. G Kartasapoetra, AG. Kartasapoetra, A. Setiady, Hukum Tanah,
Rugun Romaida Hutabarat, Luisa Srihandayani Kexia Goutama dan Yoefanca Halim Penegakan Hukum Kehutanan...

adalah hak yang dimiliki oleh suatu persekutuan hukum desa dan suku, dimana para warga masyarakat persekutuan hukum tersebut mempunyai hak untuk menguasai tanah, yang pelaksanaannya diatur oleh ketua persekutuan kepala suku atau kepala desa yang bersangkutan. ${ }^{28}$

Faktanya pemisahan hutan adat dari hutan negara dan hak ulayat ini masih terabaikan dan kriminalisasi masyarakat hukum adat masih terus terjadi. Terdapat kasus yang dikemukakan oleh Yayasan Lembaga Bantuan Hukum Indonesia yakni di mana terdapat dua anggota kesatuan masyarakat hukum adat nagari Koto Malintang Kecamatan Tanjung Raya Kabupaten Agam, Agusri Masnefi dan Erdi Datuak Samiak yang mendekam ditahanan Polres Agam sejak 27 September 2017. Dugaan tindak pidana yang dikenakan terhadap Agusri Masnefi adalah "Melakukan penebangan pohon dalam kawasan hutan secara tidak sah", sebagaimana yang dimaksud dalam Pasal 82 ayat (1) huruf c UU P3H dan terancam hukuman penjara paling lama lima tahun dan denda sedikitnya lima ratus juta rupiah. Masyarakat sendiri hanya mengetahui bahwa tanah tersebut

Jaminan Undang- Undang Pokok Agraria Bagi Keberhasilan Pendayagunaan Tanah, Jakarta: Bina aksara, 1985, hlm. 88 


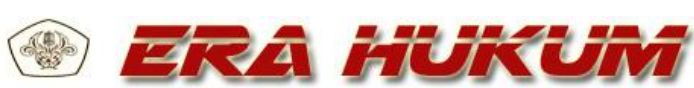
Gurnal Glmiah Glmu Glukum

Vol. 16, No. 2, Oktober 2018

Rugun Romaida Hutabarat, Luisa Srihandayani Kexia Goutama dan Yoefanca Halim Penegakan Hukum Kehutanan...

adalah parak, ulayat suku tanjung. Titik penebangan berada pada hamparan datar dekat sawah-sawah dan peladangan masyarakat yang selama ini telah mereka kelola secara turun temurun. Masyarakat sadar sebagai bagian dari warga negara Republik Indonesia mereka harus menghormati hukum, karena itu pula sekalipun menebang kayu di parak atau di ulayat-ulayat suku, masyarakat tetap berkoordinasi dengan jorong dan wali nagari sebagai representasi pemerintah RI, dalam kasus ini sudah ada rekomendasi dari jorong dan wali nagari. Berbekal surat izin ini Agusri Masnefi meminta tolong kepada bantuan Erdi Dt. Samiak untuk menebang dua pohon kayu bayur. Namun kemudian Erdi Dt. Samiak yang sedang menebang kayu ditangkap oleh Tim Gabungan Polisi Kehutanan dan Polres Agam. Ia pun memperlihatkan surat yang dimilikinya namun tidak dihiraukan oleh penegak hukum. Ia langsung dibawa ke Kepolisian Resor Agam pada 27 September Tahun 2017. ${ }^{29}$

Kekhawatiran masyarakat terhadap kemungkinan dikriminalisasi melalui UU P3H pun semakin tinggi lantaran banyak pengalaman masyarakat telah dikriminalisasi melalui UU Kehutanan

29 http://www.ylbhi.or.id/2017/11/menebangkayu-di-tanah-ulayat-dua-orang-masyarakat-

yang secara substansi memiliki banyak kemiripan dengan UU P3H. Mengingat UU P3H itu sendiri merupakan Lex Specialis dari UU Kehutanan. Misalnya dalam Pasal 12 huruf a dan b UU P3H yang menyatakan bahwa "Setiap orang dilarang: a. melakukan penebangan pohon dalam kawasan hutan yang tidak sesuai dengan izin pemanfaatan hutan dan b. melakukan penebangan pohon dalam kawasan hutan tanpa memiliki izin yang dikeluarkan oleh pejabat yang berwenang". Pasal tersebut hampir serupa dengan Pasal 50 ayat (3) huruf e UU Kehutanan yang menyebutkan bahwa "setiap orang dilarang menebang pohon atau memanen atau memungut hasil hutan di dalam hutan tanpa memiliki hak atau izin dari pejabat yang berwenang".

Dalam kasus tertentu, pelanggaran terhadap hak masyarakat hukum adat ini cukup mengkhawatirkan yang mana bahkan aparat penegak hukum menggunakan upaya kekerasan. Hal ini terjadi pada Bulan November 2011 di mana masyarakat adat Pekasa, didatangi Dinas Kehutanan Provinsi NTB bersama tim gabungan Pemerintah Daerah untuk mengusir Masyarakat Adat Pekasa dai tempat tinggalnya dengan alasan tanah

adat-ditetapkan-tersangka/ diakses pada tanggal 23 Februari 2018. 


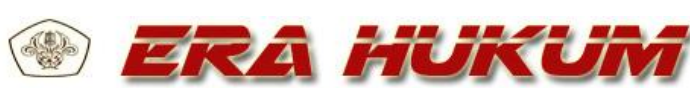
Gurnal Glmiah Glmu Glukum

Vol. 16, No. 2, Oktober 2018

Rugun Romaida Hutabarat, Luisa Srihandayani Kexia Goutama dan Yoefanca Halim Penegakan Hukum Kehutanan...

yang ditempati merupakan wilayah hutan lindung. Selanjutnya pada 21 Desember 2011, sekitar 30 personel yang terdiri dari TNI, polisi, dan polisi hutan dari Kabupaten Sumbawa Barat dengan membawa senjata laras panjang mendatangi wilayah Pekasa dan membakar tumah tempat tinggal Masyarakat Adat Pekasa. Tanpa dialog dan diberi kesempatan menyelematkan harta benda, aparat keamanan mengusir warga, dan membakar seluruh rumah warga, dari semua itu hanya tersisa 1 buah masjid. ${ }^{30}$

Miris melihat berbagai perlakuan yang demikian terjadi pada masyarakat hukum adat yang seharusnya eksistensinya dilindungi oleh negara. Memahami kesalahan dan ketidakhadiran negara itu nampaknya telah dimulai dari rumusan perundangundangan yang keliru. Menilik dalam materi Pasal 11 UU P3H maka disebutkan bahwa :

(1) Perbuatan perusakan hutan sebagaimana dimaksud dalam Undang-Undang ini meliputi kegiatan pembalakan liar dan/atau penggunaan kawasan hutan secara tidak sah yang dilakukan secara terorganisasi.

(2) Perbuatan perusakan hutan secara terorganisasi merupakan kegiatan yang dilakukan oleh suatu kelompok yang terstruktur,

${ }^{30}$ Putusan Mahkamah Konstitusi No. 95/PUUXII/2014, hlm. 15.

yang terdiri atas 2 (dua) orang atau lebih, dan yang bertindak secara bersamasama pada waktu tertentu dengan tujuan melakukan perusakan hutan.

(3) Kelompok terstruktur sebagaimana dimaksud pada ayat (2) tidak termasuk kelompok masyarakat yang bertempat tinggal di dalam dan/atau di sekitar kawasan hutan yang melakukan perladangan tradisional dan/atau melakukan penebangan kayu di luar kawasan hutan konservasi dan hutan lindung untuk keperluan sendiri dan tidak untuk tujuan komersial.

Namun hal itu kemudian menjadi ganjil manakala dalam Pasal 11 ayat (4) dituliskan "Masyarakat yang bertempat tinggal di dalam dan/atau di sekitar kawasan hutan yang melakukan penebangan kayu di luar kawasan hutan konservasi dan hutan lindung untuk keperluan sendiri dan tidak untuk tujuan komersial harus mendapat izin dari pejabat yang berwenang sesuai dengan ketentuan peraturan perundangundangan." Bahkan dalam pasal-pasal lain misalnya Pasal 12 huruf b UU P3H dapat kita temukan kembali bahwa "Setiap orang dilarang melakukan penebangan pohon dalam kawasan hutan tanpa memiliki izin yang dikeluarkan oleh pejabat yang berwenang”. Pada 


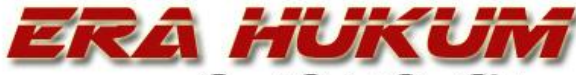 Gurnal Glmiah Glmu Glukum \\ Vol. 16, No. 2, Oktober 2018}

Pasal 82, tindakan setiap orang yang memanfaatkan hutan tanpa izin ini bahkan diberi sanksi pidana. Bunyi Pasal

82 UU P3H itu sendiri yakni :

(1) Orang perseorangan yang dengan sengaja:

a. melakukan penebangan pohon dalam kawasan hutan yang tidak sesuai dengan izin pemanfaatan hutan sebagaimana dimaksud dalam Pasal 12 huruf a;

b. melakukan penebangan pohon dalam kawasan hutan tanpa memiliki izin yang dikeluarkan oleh pejabat yang berwenang sebagaimana dimaksud dalam Pasal 12 huruf $b$; dan/atau

c. melakukan penebangan pohon dalam kawasan hutan secara tidak sah sebagaimana dimaksud dalam Pasal 12 huruf c dipidana dengan pidana penjara paling singkat 1 (satu) tahun dan paling lama 5 (lima) tahun serta pidana denda paling sedikit Rp500.000.000,00 (lima ratus juta rupiah) dan paling banyak Rp2.500.000.000,00 (dua miliar lima ratus juta rupiah).

(2) Dalam hal tindak pidana sebagaimana dimaksud pada ayat (1) dilakukan oleh orang perseorangan yang bertempat tinggal di dalam dan/atau di sekitar kawasan hutan, pelaku

\footnotetext{
${ }^{31}$ Pasal 50 ayat (3) huruf e dan i Undang-Undang Nomor 41 Tahun 1999 tentang Kehutanan menyatakan bahwa setiap orang dilarang:

e. menebang pohon atau memanen atau memungut hasil hutan di dalam hutan tanpa memiliki hak atau izin dari pejabat yang berwenang;
}

Rugun Romaida Hutabarat, Luisa Srihandayani Kexia Goutama dan Yoefanca Halim Penegakan Hukum Kehutanan...

dipidana dengan pidana penjara paling singkat 3 (tiga) bulan dan paling lama 2 (dua) tahun dan/atau pidana denda paling sedikit Rp500.000,00 (lima ratus ribu rupiah) dan paling banyak Rp500.000.000,00 (lima ratus juta rupiah).

Bila melihat dalam berbagai contoh kasus di atas, pasal-pasal seperti inilah yang digunakan untuk mengkriminalisasi masyarakat hukum adat. Mengenai pasal-pasal demikian, Mahkamah Konstitusi melalui Putusan Mahkamah Konstitusi No. 95/PUUXII/2014 telah memberikan penafsiran terhadap Pasal 50 ayat (3) huruf e dan i UU Kehutanan ${ }^{31}$ yang substansinya hampir serupa dengan Pasal 11 ataupun Pasal 12 UU P3H yakni bahwa Pasal 50 ayat (3) huruf e dan i dinyatakan bertentangan dengan Undang-Undang Dasar Negara Republik Indonesia Tahun 1945 sepanjang tidak dimaknai bahwa ketentuan yang dimaksud dikecualikan terhadap masyarakat yang hidup secara turun temurun di dalam hutan dan tidak ditujukan untuk kepentingan komersial. ${ }^{32}$ Melalui penafsiran tersebut maka ketentuan larangan ataupun

i. menggembalakan ternak di dalam kawasan hutan yang tidak ditunjuk secara khusus untuk maksud tersebut oleh pejabat yang berwenang;

32 Putusan Mahkamah Konstitusi Nomor 95/PUU-XII/2014, hlm. 185. 


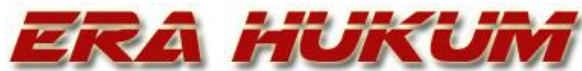 Gurnal Glmiah Glmu Glukum \\ Vol. 16, No. 2, Oktober 2018}

pengkriminalisasian tidak dapat diberlakukan bagi masyarakat hukum adat yang telah hidup turun-temurun dan memanfaatkan hutan untuk tujuan nonkomersial. Dengan adanya putusan ini seharusnya para aparat penegak hukumpun menindaklanjutinya sampai pada UU P3H yang merupakan peraturan lebih khusus daripada UU Kehutanan itu sendiri. Apalagi dalam substansi yang hampir serupa yakni mengenai pemanfaatan hutan dengan izin dari pejabat yang berwenang.

Namun, lagi-lagi adanya penguatan kedudukan bagi masyarakat hukum adat melalui putusan mahkamah konstitusi itu tidak dihiraukan oleh aparat penegak hukum karena pada nyatanya sampai sekarang ini masih banyak masyarakat hukum adat dikriminalisasi. Aliansi Masyarakat Adat Nusantara (AMAN) mencatat masyarakat adat masih menjadi salah pihak yang rentan terhadap praktik kriminalisasi bermotif sumber daya alam dan berdasarkan data pada akhir tahun 2015 telah tercatat 220 kasus kriminalisasi terhadap masyarakat hukum adat di seluruh Indonesia. ${ }^{33}$ Berlanjutnya kriminalisasi ini termasuk

33

https://www.kontras.org/home/index.php?modul e=pers\&id=2282, diakses pada tanggal 24 Maret 2018

34 Suprima Ollifica Pratasi, "Implementasi Teori Keadilan Komutatif terhadap Pelaku
Rugun Romaida Hutabarat, Luisa Srihandayani Kexia Goutama dan Yoefanca Halim Penegakan Hukum Kehutanan...

pula kasus yang dialami Agus Manesfri yang masih saja terjadi setelah adanya Putusan Mahkamah Konstitusi Nomor 95/PUU-XII/2014.

Permasalahan mengenai hutan adat ini telah menimbulkan ketidakadilan bagi masyarakat hukum adat. Mengenai teori keadilan, salah satu konsep yang diajarkan oleh Aristoteles yaitu keadilan distributif menuntut bahwa setiap orang harus mendapat apa yang menjadi hak atau jatahnya; suum cuique tribuere (to reach his own). ${ }^{34}$ Masing-masing orang mendapat bagian sesuai dengan proporsinya bergantung pada posisi, kedudukan, ataupun kondisi individu tersebut. Pemenuhan keadilan distributif merupakan tugas pemerintah terhadap warganya, menentukan apa yang dapat dituntut oleh warga masyarakat. ${ }^{35}$ Dalam konteks ini, pemerintah harus dapat secara bijaksana merumuskan dengan jelas berbagai peraturan sesuai dengan hak-hak masyarakat dan tentu menjamin pula proses implementasinya. Ketika pemerintah berhasil memenuhi hak-hak masyarakat sebagaimana mestinya maka terciptalah keadilan itu. Lebih lanjut, John Rawls berpendapat bahwa keadilan

Pemerkosaan Menurut Pasal 285 KUHP”, Jurnal Lex et Societatis, Volume II Nomor 5, 2014, hlm. 56.

${ }^{35}$ Ibid. 


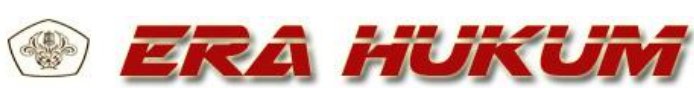
Gurnal Glmiah Glmu Glukum

Vol. 16, No. 2, Oktober 2018

Rugun Romaida Hutabarat, Luisa Srihandayani Kexia Goutama dan Yoefanca Halim Penegakan Hukum Kehutanan...

adalah kebajikan utama dari hadirnya institusi-institusi sosial (social institutions). Akan tetapi, menurutnya, kebaikan bagi seluruh masyarakat tidak dapat mengesampingkan atau menggangu rasa keadilan dari setiap orang yang telah memperoleh rasa keadilan, khususnya masyarakat lemah. ${ }^{36}$ Teori keadilan John Rawls menolak jika lenyapnya kebebasan bagi sejumlah orang dapat dibenarkan oleh hal lebih besar yang didapatkan oleh orang lain, bahkan keadilan tidak membiarkan pengorbanan yang dipaksakan pada segelintir orang diperberat oleh sebagian besar keuntungan yang dinikmati banyak orang. ${ }^{37}$

Mengenai hak masyarakat hukum adat, maka seharusnya pemerintah memberikan jaminan akan pemenuhan hak masyarakat hukum adat tersebut yang sebenarnya telah diatur dalam UU P3H serta dilengkapi dalam Putusan Mahkamah Konstitusi Nomor 95/PUUXII/2014. Kenyataan bahwa masih banyak aparat penegak hukum yang mengkriminalisasi masyarakat hukum adat justru menimbulkan ketidakadilan

36 Pan Mohamad Faiz, "Teori Keadilan John Rawls", Jurnal Konstitusi, Volume 6 Nomor 1, 2009, hlm. 139.

${ }^{37}$ Bambang Daru Nugroho, Hukum Adat : Hak Menguasai Negara atas Sumber Daya Alam

bagi masyarakat hukum adat itu sendiri.

Apalagi, masyarakat hukum adat dikriminalisasi hanya karena memanfaatkan hasil hutan yang digunakan untuk pemenuhan kebutuhan hidup. Padahal melihat kedudukan masyarakat hukum adat tersebut sebagai bagian dari warga negara Indonesia maka sesuai dengan Pasal 33 ayat (3) UUD NRI 1945, "Bumi dan air dan kekayaan alam yang terkandung di dalamnya dikuasai oleh negara dan dipergunakan untuk sebesar-besar kemakmuran rakyat". Hal inilah yang perlu menjadi perhatian pemerintah..

\section{Penutup}

\section{Kesimpulan}

a. Eksistensi masyarakat hukum adat beserta dengan hak-hak ulayatnya masih dihargai, dihormati, dan diakui sepanjang masih hidup dan sesuai dengan perkembangan masyarakat, kepentingan nasional, dan prinsip-prinsip Negara Kesatuan Republik Indonesia. Hal ini tercantum dalam berbagai peraturan perundang-undangan seperti Pasa; 18 B ayat (2) UUD

Kehutanan dan Perlindungan terhadap Masyarakat Hukum Adat, (Bandung: Refika Aditama, 2015), hlm. 117. 


\section{ERA Gurnal Glmiah Glmu Glukum \\ Vol. 16, No. 2, Oktober 2018}

Rugun Romaida Hutabarat, Luisa Srihandayani Kexia Goutama dan Yoefanca Halim Penegakan Hukum Kehutanan...

NRI 1945, UUPA, UU HAM, dsb.

Namun pengakuan tersebut masih lemah lantaran belum terdapat aturan operasional yang mengatur lebih lanjut dan tidak adanya pengaturan mengenai pendaftaran hutan ulayat itu sendiri sehingga masyarakat hukum adat tidak memiliki bukti yang otentik yang menjadi legitimasi keberadaannya.

b. Penegakan hukum UU P3H belum dapat mewujudkan keadilan bagi masyarakat hukum adat di Indonesia. Permasalahan dimulai dari tataran regulasi yang tidak menguntungkan bagi posisi masyarakat hukum adat. Bahkan, meskipun mahkamah konstitusi telah memberikan penafsiran pada UU Kehutanan yang substansiya hampir serupa dengan materi UU $\mathrm{P} 3 \mathrm{H}$, hal itu tidak membuat pemerintah mempertimbangkan kembali pengaturan UU $\mathrm{P} 3 \mathrm{H}$. Berbagai kriminalisasi terus berlanjut bahkan hingga sekarang ini. Padahal penjaminan dan perlindungan hak masyarakat adat adalah kewajiban pemerintah.

\section{Saran}

a. Masyarakat hukum adat tidak hanya perlu dihargai, dihormati, dan diakui

secara yuridis saja namun harus terdapat peran nyata dari pemerintah baik itu dalam bentuk regulasi ataupun gerakan konkret sehingga terdapat bentuk pengakuan nyata bagi masyarakat hukum adat sebagai bagian dari warga negara Indonesia yang tetap tunduk pada hukum dan kepentingan nasional.

b. Perlu adanya perhatian khusus dari pemerintah untuk mempertimbangkan beberapa pasal dalam UU P3H yang belum memberikan keadilan bagi masyarakat hukum adat serta mengawasi implementasi dari peraturan-peraturan yang ada.

\section{Daftar Pustaka}

\section{A. Buku}

Asshiddiqie, Jimly. Green Constitution: Nuansa Hijau Undang-Undang Dasar Negara Republik Indonesia Tahun 1945. Rajawali Pers, Jakarta, 2009.

Daru Nugroho, Bambang. Hukum Adat :

Hak Menguasai Negara atas Sumber Daya Alam Kehutanan dan Perlindungan terhadap Masyarakat Hukum Adat. Refika Aditama, Bandung, 2015.

Mahmud Marzuki, Peter. Penelitian Hukum. Kencana, Jakarta, 2010.

Manan, Bagir. Pertumbuhan dan Perkembangan Konstitusi Suatu 


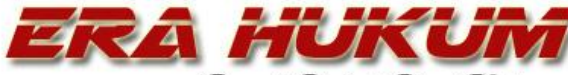 Gurnal Glmiah Glmu Glukum \\ Vol. 16, No. 2, Oktober 2018}

Negara. Mandar Maju, Bandung, 1995.

Pide, Suriyaman Mustari. Hukum Adat Dahulu, Kini, dan Akan Datang. Prenadamedia Group, Jakarta, 2014.

Salim. Hukum, Kehutanan \& Hukum Perkebunan di Indonesia. Sinar Grafika, Jakarta, 2010.

Slamet Kurnia, Titon. Dkk. Pendidikan

Hukum, Ilmu Hukum dan

Penelitian Hukum di Indonesia:

Sebuah Reorientasi. Pustaka

Pelajar, Yogyakarta, 2013.

Soemitro, Rony Hanitiyo. Metode

Penelitian Hukum dan Juri Metri.

Ghalia Indonesia, Jakarta, 1994.

Thaib, Dahlan. Teori dan Hukum Konstitusi. Raja Grafindo Persada, Jakarta, 2001.

\section{B. Jurnal}

Daru Nugroho, Bambang. "Pengelolaan Hak Ulayat Kehutanan yang Berkeadilan dalam Kaitan Pemberian Izin HPH Dihubungkan dengan Hak Menguasai Negara atas Sumber Daya Alam", Jurnal Hukum Litigasi, Volume 11 Nomor 1, April 2010.

Mohamad Faiz, Pan "Teori Keadilan John Rawls", Jurnal Konstitusi, Volume 6 Nomor 1, 2009.

Ollifica Pratasi, Suprima. "Implementasi Teori Keadilan Komutatif terhadap Pelaku Pemerkosaan Menurut Pasal 285 KUHP”, Jurnal Lex et Societatis, Volume II Nomor 5, 2014.

\section{Undang-undang}

Undang-Undang Dasar Negara Republik Indonesia Tahun 1945
Rugun Romaida Hutabarat, Luisa Srihandayani Kexia Goutama dan Yoefanca Halim Penegakan Hukum Kehutanan...

Undang-Undang Nomor 5 Tahun 1960 tentang Peraturan Dasar PokokPokok Agraria

Undang-Undang Nomor 41 Tahun 1999 tentang Kehutanan

Undang-Undang Nomor 18 tahun 2013 tentang Pencegahan dan Pemberantasan Perusakan Hutan

Peraturan Pemerintah Nomor 24 Tahun 1997 tentang Pendaftaran Tanah

\section{Putusan Mahkamah Konstitusi}

Putusan Mahkamah Konstitusi No. 95/PUU-XII/2014

\section{E. Website}

http://www.aman.or.id/wpcontent/uploads/2017/02/PROFIAMA N_Update_Bahasa_Oct2016.pdf

http://www.aman.or.id/wpcontent/uploads/2015/05/Siaran-

Pers-Pernyataan-AMAN-dalamMemperingati-2-tahun-PutusanMK-35.pdf

http://www.kpa.or.id/news/blog/bebask an-kakek-sudjana-hentikankriminalisasi-petani-hapus-uu-p3hjalankan-reforma-agraria/ http://www.ylbhi.or.id/2017/11/meneba ng-kayu-di-tanah-ulayat-dua-orangmasyarakat-adat-ditetapkantersangka/

https://www.kontras.org/home/index.ph p? module $=$ pers $\& \mathrm{id}=2282$ https://properti.kompas.com/read/2016/ 01/06/061504721/Area.Konflik.Agr aria.Terluas.di.Sektor.Perkebunan.d $\underline{\text { an.Kehutanan }}$ 